\title{
Expression and regulation of osteopontin and connective tissue growth factor transcripts in rat anterior pituitary
}

\author{
J Ehrchen, H Heuer, R Sigmund, M K-H Schäfer ${ }^{\mathbf{1}}$ and K Bauer \\ Max-Planck-Institut für Experimentelle Endokrinologie, PO Box 610309, D-30603 Hanover, Germany \\ ${ }^{1}$ Institut für Anatomie und Zellbiologie, Philipps-Universität Marburg, Robert-Koch-Strasse 6, D-35037 Marburg/Lahn, Germany \\ (Requests for offprints should be addressed to K Bauer; Email: karl.bauer@mpihan.mpg.de) \\ (J Ehrchen is now at Institut für Experimentelle Dermatologie, Universitäts-Hautklinik Münster, Von-Esmarch-Strasse 56, D-48149 Münster, Germany) \\ ( $\mathrm{H}$ Heuer is now at College of Physicians and Surgeons, Columbia University, Department of Pathology, 630 West 168th Street, New York, \\ New York 10032, USA)
}

\begin{abstract}
Cell-cell interactions are important regulatory elements in anterior pituitary (AP) physiology. As model systems to study pituitary cell-cell interactions, AP cells kept either as monolayers or as organotypic reaggregate cultures were analyzed by differential display PCR. We identified six cDNA fragments (osteopontin (Opn), connective tissue growth factor (CTGF), $\alpha_{\mathrm{v}}$-integrin, cathepsin $\mathrm{H}$, lysozyme and $\mathrm{O}$-acetyl $\mathrm{GD}_{3}$ ganglioside synthase) that showed elevated expression in monolayers compared with reaggregate cultures and the AP. The adenohypophyseal mRNA expression of Opn and CTGF, two secreted signaling substances, was studied in more detail.

In situ hybridization histochemistry revealed that Opn mRNA expression is restricted to a subpopulation of
\end{abstract}

gonadotropes whereas CTGF hybridization signals could not be ascribed to any known cell type. Opn transcript levels were downregulated in the APs of lactating rats and decreased when rats received s.c. injections of $17 \beta$ estradiol for 5 days. The mRNA expression was higher in male than in female rats and increased after gonadectomy. CTGF transcript levels were higher in male compared with female rats and were increased in pregnant rats and in rats treated for 5 days with triiodothyronine or dexamethasone.

These results indicate that Opn and CTGF may be of physiological importance as local communication factors in the AP.

Journal of Endocrinology (2001) 169, 87-96

\section{Introduction}

The anterior pituitary (AP), the master gland of the endocrine system, is dynamically controlled by a multitude of regulatory mechanisms which have to be integrated at this central structure according to the physiological conditions and the needs of the body. The development, maintenance and function of the highly differentiated cell types of the AP is determined not only by peripheral and hypothalamic signals, including their corresponding receptors, but also by a multitude of intrapituitary chemical mediators that act via paracrine, autocrine or juxtacrine communication mechanisms (for review see Denef 1994, Renner et al. 1996, Ray \& Melmed 1997).

Meanwhile, a vast array of signaling molecules (e.g. bioactive peptides, cytokines, growth and differentiation factors as well as extracellular membrane components) have been identified and for some of them we are beginning to understand partly their diverse functions. Nevertheless, for the delicate balance of pituitary homeostasis many more intrapituitary communication factors might be required.
As a model system to search for new factors that are involved in pituitary cell-cell interactions we kept dispersed AP cells either as monolayer cultures or in the form of the organotypic reaggregation cell culture system developed by the group of Denef (Denef et al. 1989). In the latter system, pituitary cells do not associate randomly but form three-dimensional tissue-like structures (Vanderschueren et al. 1982) with intimate cell-cell contacts and interactions.

To identify genes that are regulated by cell-cell interactions and which may be involved in intrapituitary cell-cell communication, we compared the gene expression of the differently cultured pituitary cells by the differential display PCR (DD-PCR) technique. Using only a limited set of arbitrary primers, we detected several DD-PCR amplification products. After identification of their nucleotide sequences, the differential expression of most DD-PCR amplification products could be verified by Northern blot analysis. Two of these products, namely osteopontin (Opn) and connective tissue growth factor (CTGF), are known secreted growth factors that are expressed by a variety of tissues and organs. Surprisingly, 
neither peptide has been detected in the AP as yet. Since Opn (for review see Denhardt \& Noda 1998, Rittling \& Denhardt 1999) and CTGF (for review see Brigstock 1999, Lau \& Lam 1999) have been recognized as chemical mediators that are especially important during development and tissue remodeling processes, we were interested in identifying the cell types synthesizing these regulatory peptides in the AP and in studying their expression under various experimental conditions.

\section{Materials and Methods}

\section{Animals}

Sprague-Dawley rats were used. The animals, maintained according to the guidelines of the Animal Welfare Committee of the Medizinische Hochschule Hanover, had free access to water and standard laboratory chow. An ambient temperature of $22{ }^{\circ} \mathrm{C}$ and alternating $12 \mathrm{~h}$ light: $12 \mathrm{~h}$ darkness cycles were controlled automatically.

To study the influence of peripheral hormones on the expression of CTGF and Opn, adult (4- to 6-month-old) male and female rats were gonadectomized and killed 2 weeks after surgery. Alternatively, adult male rats received a single s.c. injection of dexamethasone $(100 \mu \mathrm{g} /$ $100 \mathrm{~g}$ body weight $(\mathrm{BW}))$, testosterone $(200 \mu \mathrm{g} / 100 \mathrm{~g}$ $\mathrm{BW})$, triiodothyronine $\left(\mathrm{T}_{3}\right)(10 \mu \mathrm{g} / 100 \mathrm{~g} \mathrm{BW})$, 17ßestradiol $(0.5 \mu \mathrm{g} / 100 \mathrm{~g} \mathrm{BW})$, aldosterone $(5 \mu \mathrm{g} / 100 \mathrm{~g}$ BW) or vehicle (sesame oil) and were killed after $6 \mathrm{~h}$, or they received the hormone injections twice-daily $(0800$ and $2000 \mathrm{~h}$ ) for 5 days. All hormones were purchased from Sigma Chemical Co. (Deisenhofen, Germany). After decapitation, APs were removed quickly and frozen in liquid nitrogen. APs were also collected from pregnant and lactating animals.

\section{Rat AP cell culture}

Immediately after decapitation, APs were removed aseptically and minced with a razor blade. Tissue blocks were treated enzymatically using trypsin and were finally dispersed mechanically to single cells, as described by Denef et al. (1989). Cells were either plated on $35 \mathrm{~mm}$ Petri dishes (coated with poly-D-lysine, plating density $\sim 1250$ cells $/ \mathrm{mm}^{2}$ ) or were allowed to reassociate into three-dimensional cell reaggregates by continuous gyratory shaking. AP cells were cultured for up to 21 days in a humidified $\mathrm{CO}_{2}$ incubator at $37^{\circ} \mathrm{C}$ in chemically defined medium containing 10\% heat-inactivated fetal calf serum (FCS) (CC Pro, Neustadt, Germany) or for 7 days without FCS in the same medium consisting of DMEM/Ham's F12 1:1 medium, supplemented with $1 \mathrm{~g} / 1 \mathrm{NaHCO}_{3}, \mathrm{BSA}$, transferrin, insulin, ethanolamine, sodium selenite, ethanol, catalase, penicillin and streptomycin (Denef et al. 1989). As indicated, heat-inactivated
FCS $(10 \% \mathrm{v} / \mathrm{v})$ was added to the culture medium at day 2 of culture. Every second day, half of the medium was replaced by fresh medium.

\section{$D D-P C R$}

DD-PCR was performed using the RNA image kit (Gen Hunter, Brookline, MA, USA) with minor modifications. Briefly, total RNA was isolated using the RNeasy system (Qiagen, Hilden, Germany) following the manufacturer's instructions. RNA was treated with desoxyribonuclease (Boehringer Mannheim, Mannheim, Germany) to remove contaminating chromosomal DNA. RNA $(0 \cdot 2 \mu \mathrm{g})$ was reverse transcribed with the arbitrary primers $\mathrm{HT}_{11}-\mathrm{A}, \mathrm{HT}_{11}-\mathrm{C}$ or $\mathrm{HT}_{11}-\mathrm{G}$. The cDNAs were amplified by PCR in the presence of $\left[\alpha_{-}{ }^{35}\right.$ S $]$ dATP (Hartmann Analytik, Braunschweig, Germany) using a Perkin-Elmer (Norwalk, CT, USA) thermal cycler. Parameters for the PCR reaction were as follows: initial denaturation at $95^{\circ} \mathrm{C}$ for $5 \mathrm{~min}$, annealing at $40^{\circ} \mathrm{C}$ for $1 \mathrm{~min}$ followed by addition of 1.25 U AmpliTag Polymerase (Perkin-Elmer) at $72{ }^{\circ} \mathrm{C}$ (hot start modus) prior to denaturation at $95^{\circ} \mathrm{C}$ for $30 \mathrm{~s}$, annealing at $40{ }^{\circ} \mathrm{C}$ for $2 \mathrm{~min}$ and $30 \mathrm{~s}$ extension at $72{ }^{\circ} \mathrm{C}$ for 40 cycles followed by a final extension at $72{ }^{\circ} \mathrm{C}$ for $7 \mathrm{~min}$.

The amplification products were visualized by autoradiography after denaturing PAGE. Amplification products showing differential expression were excised, reamplified and cloned into the pGEM-T vector (Promega, Madison, WI, USA). Plasmid DNA was isolated and the nucleotide sequence was determined from both ends of the insert using oligonucleotide primers flanking the multiple cloning site of the vector. The derived sequences were submitted to GenBank for comparison with known sequences using the BLAST algorithm (Altschul et al. 1997).

\section{Northern blot analysis}

APs (from five animals) or AP cells (approximately $10 \times 10^{6}$ cells) were homogenized in $4 \mathrm{ml}$ buffer consisting of $0.1 \mathrm{M}$ Tris, $0.5 \mathrm{M} \mathrm{LiCl}, 10 \mathrm{mM}$ EDTA, $5 \mathrm{mM}$ dithiothreitol, 1\% SDS, $\mathrm{pH}$ 8. $\operatorname{Poly}(\mathrm{A})^{+}$-enriched RNA was isolated using magnetic $\mathrm{dT}_{25}$ polystyrene beads (Deutsche Dynal, Hamburg, Germany) following the manufacturer's instructions. Poly $(\mathrm{A})^{+}$-enriched RNA $(5-15 \mu \mathrm{g})$ was size fractionated by electrophoresis in a denaturing formaldehyde/agarose gel $(2 \cdot 2 \mathrm{M}$ formaldehyde and $1.5 \%$ agarose). The RNA was capillary transferred to a nylon membrane (Nytran NY $12 \mathrm{~N}$; Schleicher and Schuell, Dassel, Germany) and crosslinked by UV irradiation.

For probe synthesis, approximately $50 \mathrm{ng}$ of the cDNA fragments were randomly labeled with $\left[{ }^{32} \mathrm{P}\right] \mathrm{dCTP}$ (Hartmann Analytik) to high specific activity $\left(>10^{9}\right.$ c.p.m. $\left./ \mu \mathrm{g}\right)$ using the random primed labeling kit 
(Stratagene, La Jolla, CA, USA). Hybridizations were performed at $42{ }^{\circ} \mathrm{C}$ in $50 \%$ formamide containing $0.5 \%$ SDS, $100 \mu \mathrm{g} / \mathrm{ml}$ salmon sperm DNA, $0.5 \mathrm{M} \mathrm{NaCl}$, $12 \mathrm{mM}$ EDTA and 0.09 $\mathrm{M}$ sodium phosphate, $\mathrm{pH} 7 \cdot 4$. After washing under high stringency conditions $\left(59^{\circ} \mathrm{C}\right.$, $0 \cdot 3 \%$ SDS, $0 \cdot 2 \times$ SSPE $)(1 \times$ SSPE: $75 \mathrm{mM} \mathrm{NaCl} ; 5 \mathrm{mM}$ $\mathrm{NaH}_{2} \mathrm{PO}_{4}, 0.5 \mathrm{mM}$ EDTA, pH 7.4) membranes were exposed to X-ray films (XOMAT; Kodak, Stuttgart, Germany).

The following cDNA fragments were used: the complete coding region of rat Opn (Oldberg et al. 1986) (M14656); a $837 \mathrm{bp}$ fragment corresponding to nucleotide (nt) 1501-2337 of the cDNA encoding rat CTGF (Brauer 1997, Xu et al. 2000) (AF120275); a 3269 bp fragment corresponding to nt 449-3717 of the cDNA encoding mouse $\alpha_{\mathrm{v}}$-integrin subunit (Wada et al. 1996) (U14135); a $489 \mathrm{bp}$ fragment corresponding to nt 848-1336 of the cDNA encoding rat cathepsin $\mathrm{H}$ (Qian et al. 1990) (M38135); a 443 bp fragment corresponding to nt 62496691 of the rat lysozyme gene (Yeh et al. 1993) (L12459); a $76 \mathrm{bp}$ fragment corresponding to nt 1885-1960 of the cDNA encoding rat $\mathrm{O}$-acetyl-ganglioside synthase (Ogura et al. 1996) (D84068); the complete coding region of rat cyclophilin (Danielson et al. 1988) (M19533); and the complete coding region of rat glyceraldehyde-3-phosphate dehydrogenase (GAPDH) (Tso et al. 1985) (M17701).

\section{In situ hybridization histochemistry (ISH)}

Immediately after decapitation, APs were removed and frozen in isopentane cooled $\left(-30{ }^{\circ} \mathrm{C}\right.$ to $\left.-50{ }^{\circ} \mathrm{C}\right)$ on dry ice. Sections $(16 \mu \mathrm{m}$ thick) were cut on a cryostat, thaw mounted on silane treated slides and stored at $-80{ }^{\circ} \mathrm{C}$ until further processing.

The following cDNA fragments were used as templates for in vitro transcription: a $198 \mathrm{bp}$ fragment corresponding to nt 248-445 of the cDNA encoding rat growth hormone (GH) (Rohn \& Weigent 1995) (U62779) in a modified Bluescript KSII+ plasmid (pLS) (Schomburg 1994); a $254 \mathrm{bp}$ fragment corresponding to nt 190-443 of the cDNA encoding rat $\beta$-thyrotropin $(\beta-\mathrm{TSH})(\mathrm{Chin}$ et al. 1985) (M10902) in pLS; the complete coding region of rat $\beta$-follicle-stimulating hormone ( $\beta$-FSH) (Maurer 1987) in pLS (M36804); a $255 \mathrm{bp}$ fragment corresponding to $\mathrm{nt}$ 1566-1820 of the rat prolactin (PRL) gene (Gubbins et al. 1980 ) in pLS (J00769); a 471 bp fragment corresponding to nt 56-526 of exon 3 of the rat pro-opiomelanocortin (POMC) gene (Drouin et al. 1985) (J00759) in pGEM4; the complete coding region of rat Opn (953 bp) (Oldberg et al. 1986) in pBluescript KSII+ (M14656); and a 827 bp fragment corresponding to nt 1501-2337 of the cDNA encoding rat CTGF (Brauer 1997, Xu et al. 2000) in pGEM-T (AF120275).

To generate the RNA probes for Opn and CTGF, in vitro transcription was carried out according to the methods described by Heuer et al. (1998) using $\left[\alpha-{ }^{35}\right.$ S $]$ UTP and $\left[\alpha_{-}{ }^{35}\right.$ S $]$ CTP as radiolabeled nucleotides. All other RNA probes were generated by use of an RNA transcription kit (Boehringer Mannheim) and digoxigenin-11-UTP as the labeled nucleotide. Following synthesis, the probes for Opn, CTGF, $\beta$-FSH and POMC were subjected to mild alkaline hydrolysis to reduce the probe length to approximately 250 nucleotides.

ISH was carried out as described previously (Schäfer \& Day 1995, Heuer et al. 1998). Briefly, frozen sections were fixed in $4 \%$ buffered paraformaldehyde, treated with $0 \cdot 1 \%$ Triton X-100 in PBS, acetylated, dehydrated and dried. The sections were hybridized overnight at $58{ }^{\circ} \mathrm{C}$ in a humidified chamber using $5 \times 10^{4}$ d.p.m. $/ \mu l^{35}$ S-labeled sense or antisense cRNA probes for Opn and CTGF respectively, either alone or in combination with 50-200 ng digoxigenin-labeled cRNA probes ( $\beta$-TSH, $\beta-F S H, P R L, G H$ and POMC). The probes were diluted in hybridization buffer consisting of 50\% formamide, $10 \%$

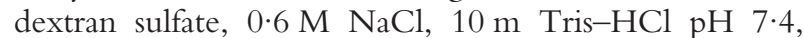
$1 \times$ Denhardt's solution (Denhardt 1966), $100 \mu \mathrm{g} / \mathrm{ml}$ sonicated salmon sperm DNA, $1 \mathrm{mM}$ EDTA and $10 \mathrm{mM}$ dithiothreitol. The sections were washed in $2 \times$ SSC $(1 \times$ SSC: $150 \mathrm{mM} \mathrm{NaCl} ; 15 \mathrm{mM}$ sodium citrate, $\mathrm{pH} 7 \cdot 2)$ and treated with RNaseA and RNaseT1. Successive washes followed at room temperature $(1 \times, 0.5 \times$, $0 \cdot 2 \times \mathrm{SSC})$ and at $65{ }^{\circ} \mathrm{C}(0 \cdot 2 \times \mathrm{SSC})$. For the detection of Opn and CTGF mRNA, the tissues were dehydrated, dipped in Kodak NTB2 nuclear emulsion and exposed for 2 weeks. Autoradiograms were developed in Kodak D19 for $4 \mathrm{~min}$ and fixed in Rapid Fix (Kodak) for $4 \mathrm{~min}$.

For the combined detection of the radiolabeled (CTGF or Opn) and the digoxigenin-labeled signals, the sections were exposed to alkaline phosphatase conjugated antidigoxigenin antibody (Boehringer Mannheim, diluted 1:500) overnight at $4{ }^{\circ} \mathrm{C}$, followed by $3 \mathrm{~h}$ incubation in chromogen solution containing nitroblue tetrazolium $(0.41 \mathrm{mM})$ and 5-bromo-4-chloro-3-indolylphosphate $(0.38 \mathrm{mM})$. The color reaction was stopped by rinsing the slides overnight in TE buffer $(10 \mathrm{mM}$ Tris-Cl, $1 \mathrm{mM}$ EDTA, pH 8). The tissue was dehydrated, dipped in Ilford K5D nuclear emulsion (Dreieich, Germany) and exposed for 2 weeks.

Detection of CD68 or complement $C_{3 b}$ receptor by immunocytochemistry (ICC) and detection of CTGF mRNA by ISH

Cryostat sections were fixed in $3.7 \%$ formalin for $5 \mathrm{~min}$, followed by successive washings in 50, 100 and 50\% acetone for $2 \mathrm{~min}$ each. After washing in Tris-buffered saline (TBS, 0.05 M Tris-HCl, $150 \mathrm{mM} \mathrm{NaCl}, \mathrm{pH} 7 \cdot 5$ ), the sections were incubated in blocking buffer consisting of TBS, $3 \%$ BSA and $5 \mathrm{mg} / \mathrm{ml}$ heparin (Gibco BRL, Eggenstein, Germany) for $30 \mathrm{~min}$. The primary antibodies (ED-1 or OX-42, both mouse anti-rat supplied by Serotec, Wiesbaden, Germany), both diluted 1:500 in 
blocking buffer, were applied separately for $1 \mathrm{~h}$ at room temperature. After three washes in TBS, the sections were incubated for $30 \mathrm{~min}$ at room temperature with biotinylated secondary antibody (rabbit anti-mouse; Dako, Hamburg, Germany) diluted 1:300 in blocking buffer. After washing in TBS (three times) the avidin-biotinylated peroxidase complex (Dako) was applied for $30 \mathrm{~min}$ at room temperature, following the recommendations of the supplier. Diaminobenzidine (Sigma fast; Sigma) was used as chromogen. After washing in $\mathrm{H}_{2} \mathrm{O}$ the sections were postfixed in $4 \%$ buffered paraformaldehyde for $10 \mathrm{~min}$ and subsequently subjected to ISH for CTGF as described above.

\section{Detection of CTGF mRNA by ISH and S-100 protein by ICC}

Cryostat sections of APs were prepared from animals that were transcardially perfused with $4 \%$ buffered paraformaldehyde. The sections were postfixed in $4 \%$ buffered paraformaldehyde for $30 \mathrm{~min}$ at room temperature and subjected to ISH using digoxigenin-labeled Opn mRNA probes as described above. Following the color reaction, the sections were incubated in TE buffer overnight, followed by three washes in TBS containing $0.1 \%$ Triton X-100 (TBS-Triton). The primary antibody (S-100, polyclonal antiserum, supplied prediluted by Immunotec, Hamburg, Germany) was applied for $1 \mathrm{~h}$ at room temperature. After washing in TBS-Triton (three times), the sections were incubated for $30 \mathrm{~min}$ at room temperature with Cy3-conjugated mouse anti-rabbit antibody (dilution 1:300; Dianova, Hamburg, Germany), rinsed with TBS, covered with mounting medium (Citifluor; Plano, Marburg, Germany) to retard fading and examined under a fluorescence microscope (Olympus BH3, New York, NY, USA).

\section{Results}

We used the DD-PCR technique to compare the gene expression in AP cells that were kept as monolayer or as reaggregate cultures. Using a limited set of only 12 arbitrary primers we detected about 100 amplification products that appeared to be differentially expressed by this screening method. After subcloning and nucleotide sequencing 36 products could be attributed to known sequences. For selected products the differential gene expression in the culture systems was verified by Northern blot analysis (Fig. 1). In addition to these probes, the mRNA expression in AP and brain was also analyzed. In agreement with the DD-PCR screening results the transcript levels of these products were always elevated in the monolayer compared with the reaggregate cultures kept either for 3 weeks in medium containing 10\% FCS (Fig. 1) or for 7 days in chemically defined medium (data

\section{Osteopontin}
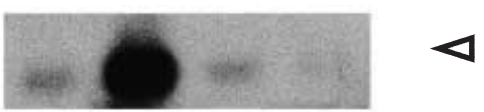

CTGF
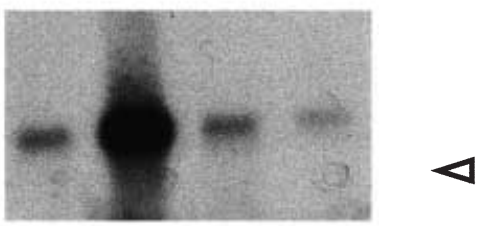

Alpha-v-integrin
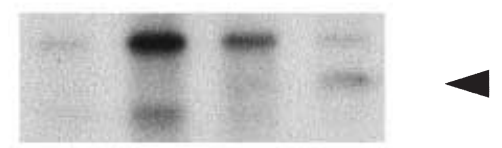

\section{Cathepsin H}
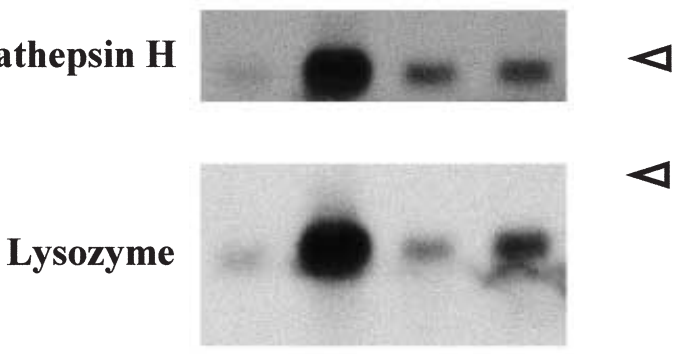

\section{O-Acetyl-GD3 Ganglioside Transferase}
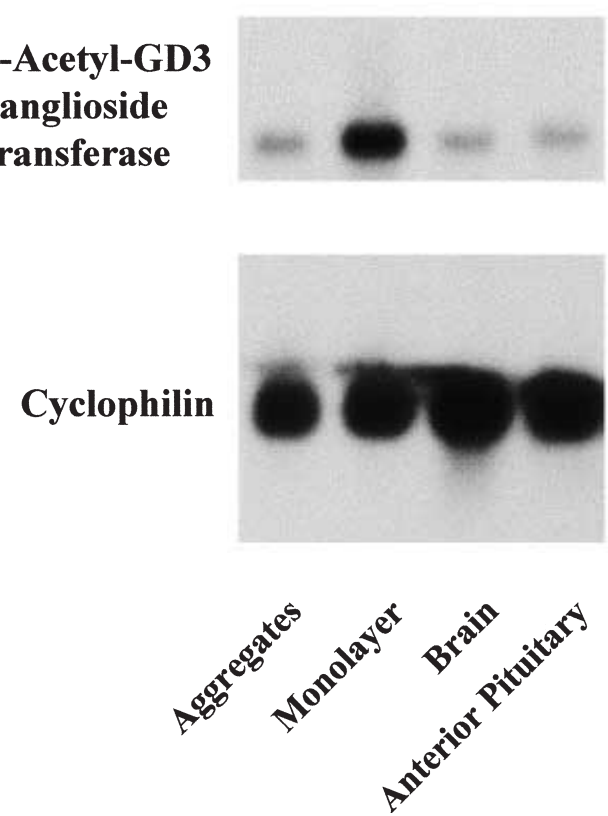

Figure 1 Differential expression of identified DD-PCR products. Poly $\left(\mathrm{A}^{+}\right)$-enriched RNA was prepared from brain and AP, as well as from AP cells cultured for 3 weeks either as monolayers or as reaggregates in medium containing 10\% FCS. Northern blot analysis was carried out as described in Materials and Methods. Cyclophilin signals were used as an internal standard. The positions of the $18 \mathrm{~S}$ (open arrowhead) and 28S (closed arrowhead) rRNA are indicated. 


\section{Osteopontin}

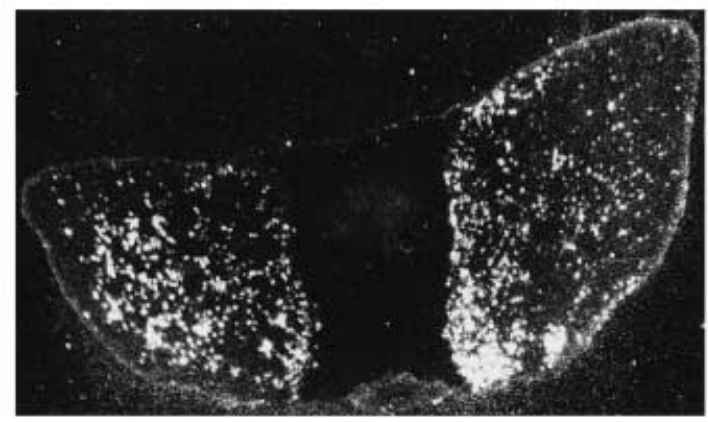

\section{CTGF}

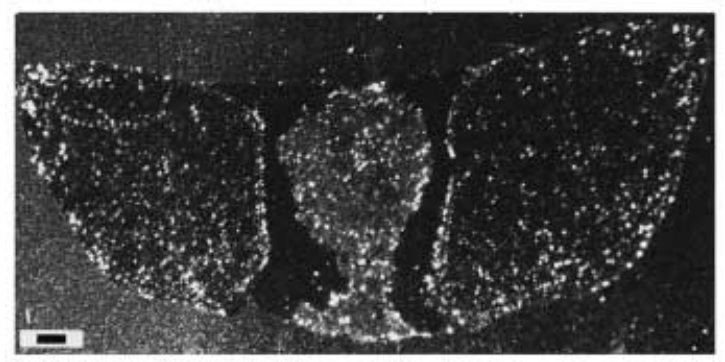

Figure 2 Analysis of Opn and CTGF mRNA expression in rat pituitary by ISH. Frozen pituitary sections of male rats were hybridized with ${ }^{35} \mathrm{~S}$-labeled riboprobes specific for Opn and CTGF as described in Materials and Methods. Hybridization signals were visualized by darkfield illumination. Staining was not observed when the sense probes for CTGF and Opn were used. Bar $=100 \mu \mathrm{m}$.

not shown). Among the differentially expressed products we detected two products which are known to act as secreted growth factors in other tissues, namely CTGF and Opn, as well as $\alpha_{\mathrm{v}}$-integrin subunit, a constituent of the well characterized Opn receptors $\alpha_{\mathrm{v}} \beta_{3}, \alpha_{\mathrm{v}} \beta_{1}$ and $\alpha_{\mathrm{v}} \beta_{5}$ (Denhardt \& Noda 1998).

\section{Localization of CTGF and Opn in the rat AP gland}

ISH was performed to analyze the mRNA distribution of Opn and CTGF in the AP. For both peptides hybridization signals were easily detected (Fig. 2). While for Opn the distribution was restricted to the AP, hybridization signals for CTGF were also found in the posterior pituitary, but not in the intermediate lobe.

To identify the cell types synthesizing these growth factors, we analyzed the mRNA distribution of Opn and CTGF with the respective ${ }^{35} \mathrm{~S}$-labeled cRNA probes and used digoxigenin-labeled RNA probes for PRL, GH, $\beta$-FSH, $\beta$-TSH and POMC to localize the hormoneproducing cells of the AP. By this method, strong hybrid- ization signals for Opn could be detected only in the $\beta$-FSH-positive gonadotropic cells (Fig. 3) but not in the other hormone-producing cells. While all Opn signals colocalized with $\beta$-FSH mRNA expressing cells, some of the cells containing $\beta$-FSH transcripts did not contain Opn mRNA, indicating that Opn transcripts are exclusively restricted to a subpopulation of gonadotropic cells.

For CTGF we were unable to identify the cell type expressing the mRNA of this growth factor. As shown in Fig. 4 CTGF transcripts do not colocalize with any cell type expressing mRNA of the AP hormones tested. To identify CTGF mRNA expression in non-hormoneproducing cell types we combined the ISH technique for CTGF with the ICC method for the detection of folliculostellate cells, macrophages and dendritic cells using antibodies against the cell marker proteins S-100, CD68 (ED1 antibodies) and complement $\mathrm{C}_{3 \mathrm{~b}}$ receptor $(\mathrm{OX}-42$ antibodies). Despite all efforts we were unsuccessful in defining the CTGF mRNA expressing cells in the AP.

\section{Regulation of transcript levels}

By autoradiography and phosphoimaging (Fujix, BAS 1000; Fuji, Japan) we analyzed the transcript levels of Opn and CTGF (normalized to GAPDH and cyclophilin respectively) in the AP of control animals (injected with sesame oil as vehicle) and in male rats that had received multiple injections of peripheral hormones (Fig. 5). When the animals were treated twice-daily for 5 days, the mRNA levels of CTGF were increased in the AP of rats injected with $\mathrm{T}_{3}(\sim 3$-fold $)$ and dexamethasone $(\sim 3$-fold $)$ but were not altered after injection of aldosterone and the sex steroids testosterone and $17 \beta$-estradiol. In contrast, Opn mRNA levels were decreased in 17 $\beta$-estradiol treated animals ( $\sim 4$-fold) and to some extent also after prolonged treatment with testosterone $(\sim 2$-fold). When the animals received only a single injection of the hormones $5 \mathrm{~h}$ prior to being killed, only the CTGF mRNA levels were increased $(\sim 6$-fold) in rats treated with dexamethasone whereas all other transcript levels were not affected by the short-term treatment.

Next we analyzed whether the transcript levels of CTGF and Opn were influenced by the gender of the animals or by conditions with altered endocrine status such as gonadectomy, pregnancy or lactation (Fig. 6). Compared with female rats, the mRNA levels of CTGF and Opn were both higher in male rats $(\sim 1 \cdot 6$-fold and $\sim 12$-fold respectively). In both genders the Opn mRNA levels increased after gonadectomy ( $\sim 11$-fold in females and $\sim 3 \cdot 5$-fold in males), whereas the CTGF transcripts were only marginally affected. The Opn mRNA levels were not altered during pregnancy but decreased ( $\sim 3$-fold) during the lactation period. In contrast, CTGF transcript levels were elevated during pregnancy $(\sim 2 \cdot 5$-fold $)$ and returned to basal levels during lactation. 
A

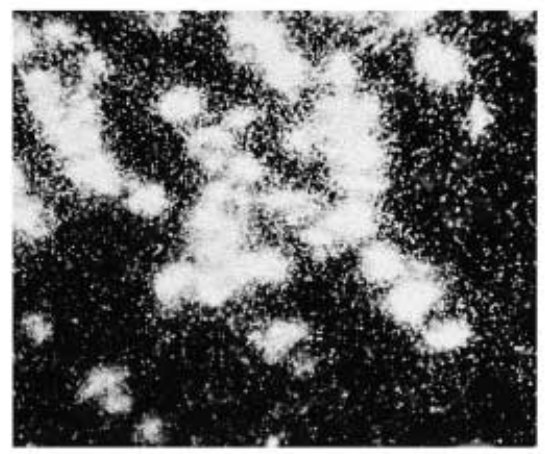

B

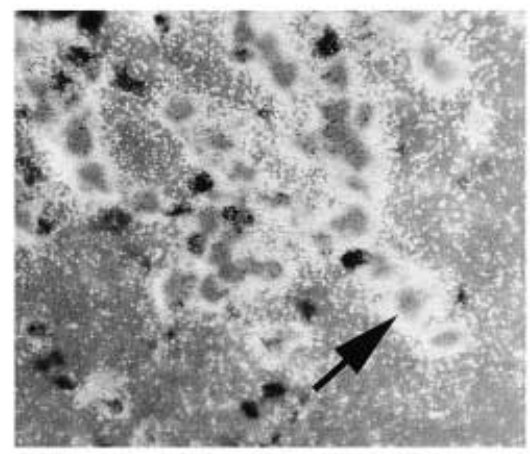

C

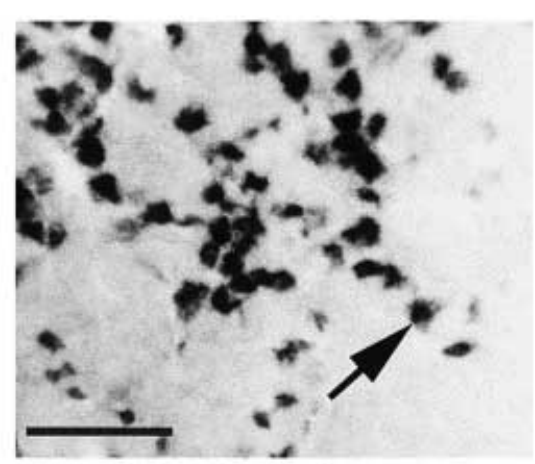

Figure 3 Analysis of Opn and $\beta$-FSH mRNA expression in rat pituitary. Frozen pituitary sections of male rats were hybridized with ${ }^{35}$ S-labeled riboprobes specific for Opn and with digoxigenin-labeled riboprobes specific for $\beta$-FSH and analyzed as described in Materials and Methods. (A) High power darkfield micrograph of Opn hybridization signals; (B) combined darkfield and brightfield illustrations of Opn and $\beta$-FSH hybridization signals; (C) brightfield micrograph of $\beta$-FSH hybridization signals. The arrow indicates the position of a $\beta$-FSH-positive cell. Staining was not observed when the sense probes for $\beta$-FSH and Opn were used. Bar $=50 \mu \mathrm{m}$.

\section{Discussion}

As shown in the extensive studies by Carl Denef and co-workers (Denef et al. 1989, Vanderschueren et al. 1982) the organotypic reaggregate cultures can be considered as an ideal model system to study paracrine as well as cell-cell interactions in the AP in contrast to the monolayer cultures in which the cellular communication systems are not preserved. By analyzing AP cells that were kept either as monolayer or as reaggregate cultures, we previously demonstrated that synthesis and secretion of thyrotropin-releasing hormone by pituitary cells is strongly influenced not only by the culture medium but also by cell-cell interactions (Peters et al. 1997). As a first step in the search for other cell signaling molecules we were interested in using a more general approach by identifying genes that are differently expressed in the two culture systems using for analysis the DD-PCR technique (Liang \& Pardee 1992). With this screening method, which is now well established, we indeed readily detected many $(n=36)$ differently expressed amplification products using only a limited set $(n=12)$ of arbitrary primers.

For most $(70 \%)$ of these products their differential expression in the monolayer and reaggregate cultures could be verified by Northern blot analysis. The fact that we identified many products that are derived from genes which are expressed at very low levels underlines the sensitivity of the DD-PCR technique. It may also be interesting to note that in the monolayer cultures most gene products were expressed at considerably higher levels not only as compared with the reaggregates but also as compared with the AP.

Among the differentially expressed gene products, we were most interested in studying CTGF and Opn in more detail. In various tissues CTGF and Opn, both secreted soluble proteins, have been recognized as very important regulatory peptides and potent growth factors. Surprisingly, however, in the AP neither CTGF nor Opn has been detected before. In line with our culture models are the reports describing increased expression of both growth factors during development, differentiation and conditions that are associated with the disruption of normal tissue structures. For example, Opn, a secreted phosphoglycoprotein containing the arginine-glycine-aspartate integrin binding motif, seems to be important in tissue remodeling processes such as tumor growth (as reviewed by Denhardt \& Noda 1998), wound healing (Liaw et al. 1998), bone resorption (Yoshitake et al. 1999) and inflammatory processes (Ashkar et al. 2000). Via interaction with its receptors (e.g. $\alpha_{\mathrm{v}} \beta_{3}$-integrin and CD44) this regulatory peptide is involved in various processes that depend on cell-cell and cell-matrix interactions (for review see Denhardt \& Noda 1998, Rittling \& Denhardt 1999). In many tissues, CTGF, a member of the family of connective tissue growth factor/cysteine-rich 6 1/nephroblastoma overexpressed proteins (CCN family), is also involved in 


\section{CTGF/GH}

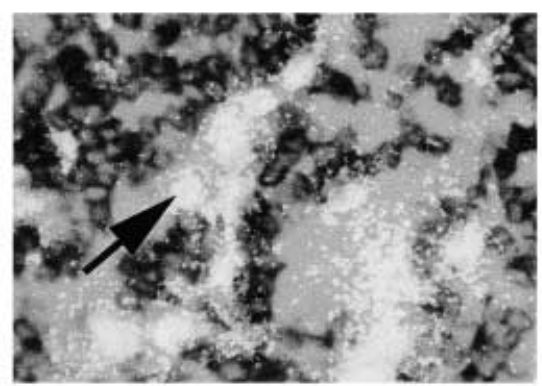

\section{CTGF/B-FSH}

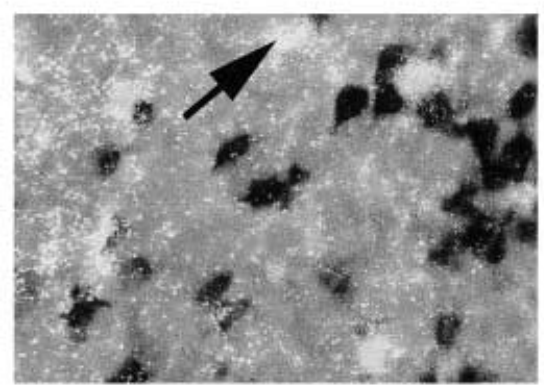

\section{CTGF/POMC}

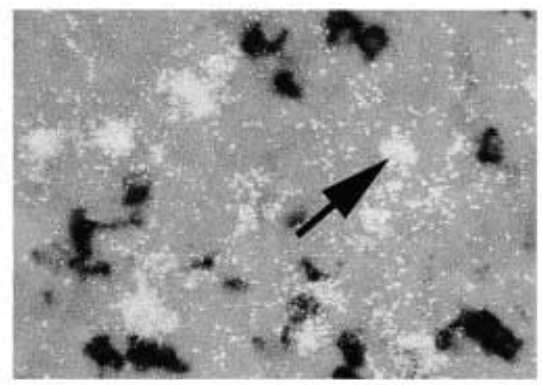

\section{CTGF/ED-1}

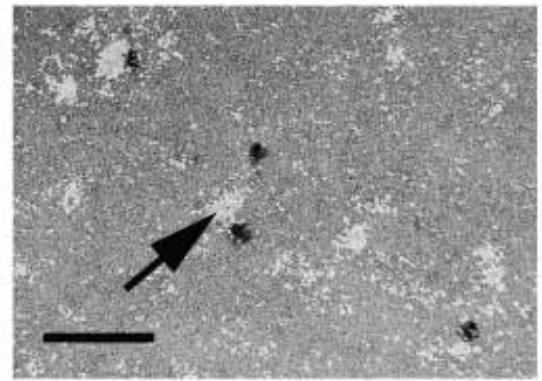

CTGF/PRL

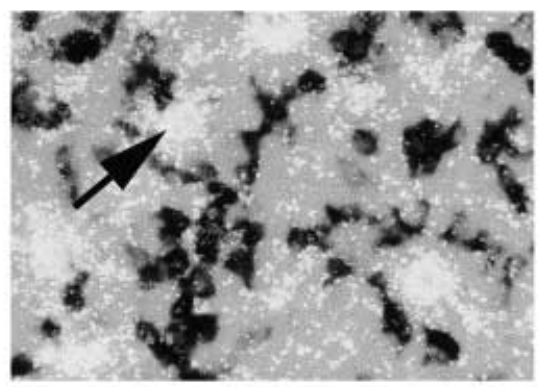

\section{CTGF/ß-TSH}

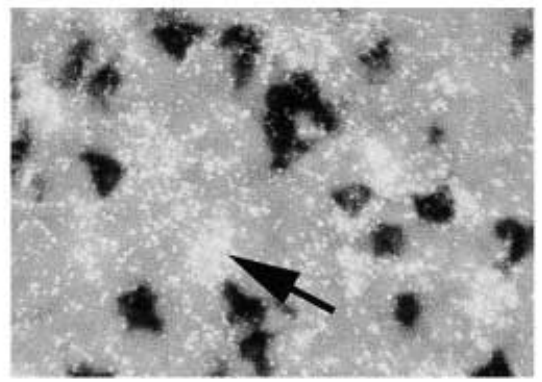

CTGF/S-100

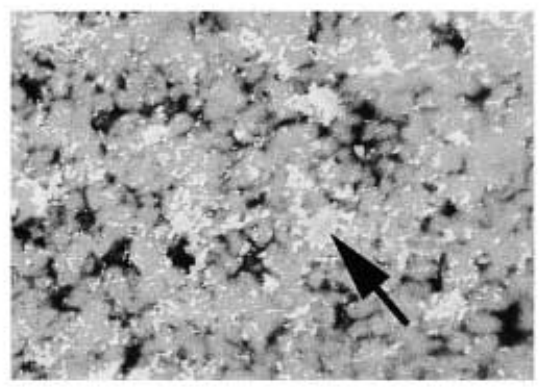

CTGF/OX-42

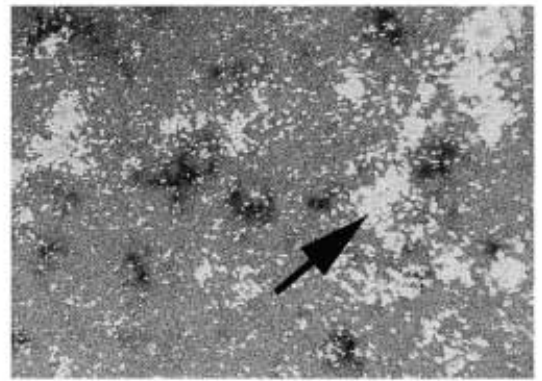

Figure 4 Analysis of CTGF mRNA expression in the rat AP. CTGF mRNA expression was analyzed using the radioactive riboprobe and the mRNA expression of the pituitary hormones GH, PRL, $\beta$-FSH, $\beta-\mathrm{TSH}$ and POMC was detected using the respective digoxigenin-labeled riboprobes. Antibodies against protein S-100 (folliculostellate cells), CD68 (macrophages; recognized by ED-1 antibodies) and complement $\mathrm{C}_{3 \mathrm{~b}}$ receptor (dendritic cells; recognized by OX-42 antibodies) were used to mark non-hormone-producing AP cells. The combined high power darkfield and brightfield micrographs are presented as indicated. The arrow indicates the position of a CTGF-positive cell. Staining was not observed without primary antibodies and also not when the sense probes for CTGF and the pituitary hormones were used. Bar $=50 \mu \mathrm{m}$. 

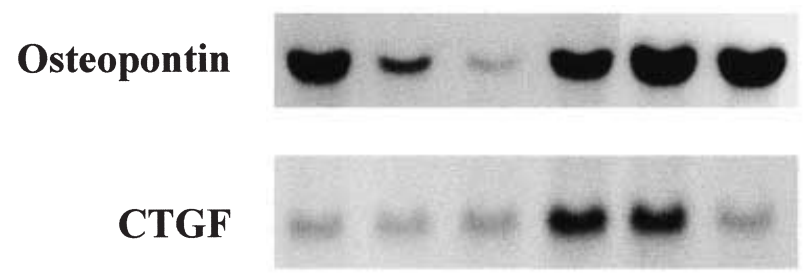

GAPDH

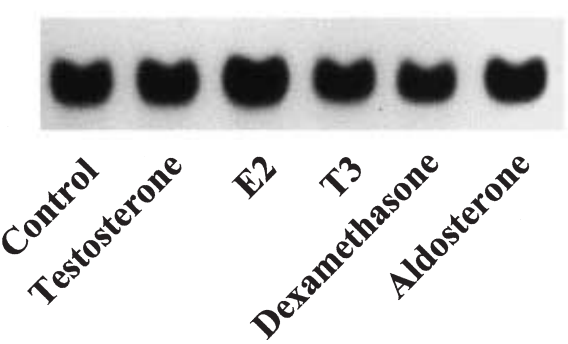

Figure 5 Hormonal regulation of adenohypophyseal Opn and CTGF mRNA steady-state levels. Male rats received twice-daily s.c. injections of dexamethasone $(100 \mu \mathrm{g} / 100 \mathrm{~g} \mathrm{BW})$, testosterone $(200 \mu \mathrm{g} / 100 \mathrm{~g} \mathrm{BW}), \mathrm{T}_{3}(10 \mu \mathrm{g} / 100 \mathrm{~g} \mathrm{BW}), 17 \beta$-estradiol $\left(\mathrm{E}_{2}\right)$ $(0.5 \mu \mathrm{g} / 100 \mathrm{~g} \mathrm{BW})$, aldosterone $(5 \mu \mathrm{g} / 100 \mathrm{~g} \mathrm{BW})$ or vehicle (sesame oil) and were killed after 5 days. The APs were prepared and the mRNA levels were analyzed by Northern blot, as described in Materials and Methods. The GAPDH signals were used as an internal standard.

various events that require cell-cell and cell-matrix interactions such as angiogenesis, tumor growth, inflammation and wound repair (for review see Lau \& Lam 1999, Brigstock 1999).

In agreement with its localization in gonadotropic cells, the adenohypophyseal Opn mRNA levels were considerably influenced by sex steroids but not by the other steroid

\section{Osteopontin}

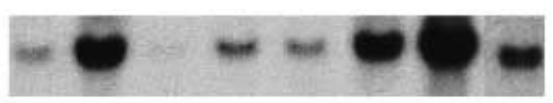

\section{CTGF}

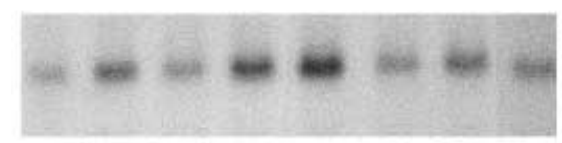

\section{Cyclophilin}
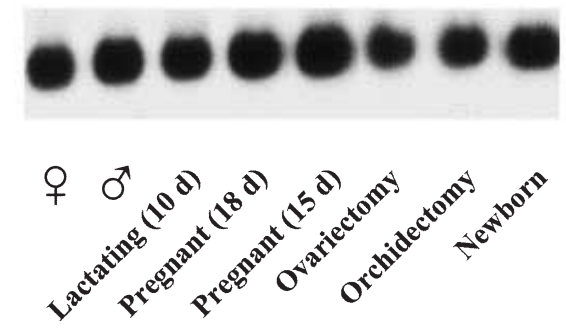

Figure 6 Influence of the endocrine status of the animals on the expression of Opn and CTGF mRNA in rat pituitaries. Northern blot analysis was performed with poly $\left(\mathrm{A}^{+}\right)$-enriched RNA prepared from the APs of male, female, lactating (day 10 of lactation), pregnant (day 18 and 15 of gestation), ovariectomized, orchiectomized and newborn rats. hormones tested. In male rats receiving high doses of steroid hormones for prolonged periods of time, the Opn mRNA levels were only significantly reduced after injection of $17 \beta$-estradiol and to a lesser extent after testosterone treatment (in part possibly due to the conversion of testosterone to $17 \beta$-estradiol). Correspondingly, after gonadectomy the Opn transcript levels were found to be increased in male and in female rats. In addition, we observed a clear gender difference with $\sim 12$-fold higher Opn mRNA levels in male compared with female rats. As known, Opn expression (which usually correlates with Opn secretion) is influenced by many agents acting on many cell types through diverse signaling pathways (for review see Denhardt \& Noda 1998). With regard to steroid hormones, Opn expression was found to be upregulated by dexamethasone in rat bone marrow stromal cell cultures (Rickard et al. 1994) and in rat bone organ cultures (Chen et al. 1996). In the experimental model of kidney stone formation, progesterone and $17 \beta$-estradiol inhibited the glyoxylic acid induced increase of Opn mRNA levels in rat kidney (Umekawa et al. 1995) whereas in mouse skin the Opn mRNA levels were enhanced when the combination of these steroids was applied to the skin of non-pregnant females (Craig \& Denhardt 1991). Increased Opn mRNA levels were also observed in the skin of pregnant and lactating mice.

In contrast, Opn transcript levels in rat AP were considerably decreased during lactation and after prolonged treatment with $17 \beta$-estradiol but were not affected during pregnancy. Thus, as in other tissues, the regulation of Opn expression in the AP seems to be very complex. In search of an explanation one might hypothesize that the effects of $17 \beta$-estradiol, the sex differences and the effects after gonadectomy might possibly be mediated by PRL since PRL synthesis and secretion is generally stimulated by $17 \beta$-estradiol (Lamberts \& Macleod 1990). The decreased Opn mRNA levels in lactating rats might also be related to the elevated PRL serum levels induced by suckling. During pregnancy, however, Opn transcript levels were not altered. Again, this might be explained by the fact that in the rat, the PRL serum levels are not increased despite elevated $17 \beta$-estradiol levels (Escalada et al. 1996). In this context it may be interesting to note that Opn is expressed in gonadotropic cells, a cell type that is surrounded by clusters of lactotropic cells (Horvath \& Kovacs 1988, Allaerts et al. 1991) and equipped with PRL receptors (Morel et al. 1994, Jin et al. 1997, Tortonese et al. 1998).

In line with this view are also the reports describing close interactions between these cell types through paracrine factors regulating gonadotrope and lactotrope functions (Denef \& Andries 1983, Seuntjens et al. 1999). Since lactation and elevated $17 \beta$-estradiol serum levels are both known to affect gonadotropic functions, it is tempting to speculate that Opn may be considered as a locally produced intrapituitary mediator of the 
hypothalamic-hypophyseal-gonadal axis. Of course, this hypothesis is rather speculative and has to await further investigation.

For CTGF, despite all efforts we have unfortunately failed to identify the pituitary cell type(s) expressing this growth factor and thus it is difficult to ascribe possible functions for this growth factor in the AP. Among the hormones tested, only dexamethasone significantly increased CTGF transcript levels after long-term treatment and even more impressively within $5 \mathrm{~h}$ after a single injection of this steroid (data not shown). A rapid and dramatic induction of CTGF mRNA and protein by dexamethasone has also been observed in cultured fibroblasts and described recently (Dammeier et al. 1998). The same authors also reported on dexamethasone induced upregulation of CTGF mRNA levels in heart, kidney and skin of mice that had been injected repeatedly with dexamethasone.

Interestingly, CTGF transcript levels in the AP were also considerably increased after long-term treatment of the animals with $\mathrm{T}_{3}$, an effect not described before in any tissue. CTGF mRNA levels were also upregulated ( $\sim$-fold) in AP cultures (monolayer and reaggregate cultures) kept for 2 days in medium supplemented with $3 \mathrm{nM} \mathrm{T}_{3}$ (not shown). However, CTGF mRNA levels were not altered after a single injection of $\mathrm{T}_{3}$ and thus it is unclear whether $\mathrm{T}_{3}$ exerts a direct effect on CTGF expression or, and more likely, acts indirectly. As known, in various tissues CTGF expression is influenced by transforming growth factor- $\beta$ and other growth factors (for review see Brigstock 1999).

On the other hand, however, it has also long been recognized that thyroid hormones induce the expression of various growth-promoting factors (e.g. GH, epidermal growth factor, nerve growth factor) and induce cell growth in various tissues (Ezzat \& Melmed 1990, Ray \& Melmed 1997). More specifically, with pituitary tumor cells it has been clearly demonstrated that $\mathrm{T}_{3}$ can induce the production and secretion of a specific pituitary growth factor with selective growth-promoting properties (Hinkle \& Kinsella 1986, Ezzat \& Melmed 1990).

Taken together, we have provided evidence for the adenohypophyseal synthesis of CTGF and Opn, both growth factors that are known as potent regulatory peptides in various tissues. In the AP, however, we have to await further studies to define the biological functions of these factors in AP physiology and/or pathophysiology and especially within the network of intrapituitary communication.

\section{Acknowledgements}

We thank Anke Turwitt, Birgit Jarck, H-O Bader, S Thiele and N Naujokat for excellent technical assistance.
We also thank Lutz Schomburg and Christian Ulke for helpful discussions and $\mathrm{V}$ Ashe for linguistic help and typing the manuscript. This work was supported by the Deutsche Forschungsgemeinschaft.

\section{References}

Allaerts W, Mignon A \& Denef C 1991 Selectivity of juxtaposition between cup-shaped lactotrophs and gonadotrophs from rat anterior pituitary in culture. Cell and Tissue Research 263 217-225.

Altschul SF, Madden TL, Schäffer AA, Zhang J, Zhang Z, Miller W \& Lipman DJ 1997 Gapped BLAST and PSI-BLAST: a new generation of protein database search programs. Nucleic Acids Research 25 3389-3402.

Ashkar S, Weber GF, Panoutsakopoulou V, Sanchirico ME, Jansson M, Zawaideh S, Rittling SR, Denhardt DT, Glimcher MJ \& Cantor H 2000 Eta-1 (osteopontin): an early component of Type-1 (cell-mediated) immunity. Science 287 860-864.

Brauer D 1997 Untersuchungen zur hormonellen Regulation der Genexpression im Gehirn. Diplomarbeit. University of Hanover.

Brigstock D 1999 The connective tissue growth factor/cysteine-rich 6 1/nephroblastoma overexpressed (CCN) family. Endocrine Reviews 20 189-206.

Chen J, Thomas HF \& Sodek J 1996 Regulation of bone sialoprotein and osteopontin mRNA expression by dexamethasone and 1,25dihydroxyvitamin D3 in rat bone organ cultures. Connective Tissue Research 34 41-51.

Chin WW, Muccini JA \& Shin L 1985 Evidence for a single rat thyrotropin-beta-subunit gene: thyroidectomy increases its mRNA. Biochemical and Biophysical Research Communications 128 1152-1158.

Craig AM \& Denhardt DT 1991 The murine gene encoding secreted phosphoprotein 1 (osteopontin): promoter structure, activity and induction in vivo by estrogen and progesterone. Gene 100 163-171.

Dammeier J, Beer HD, Brauchle M \& Werner S 1998 Dexamethasone is a novel potent inducer of connective tissue growth factor expression. Implications for glucocorticoid therapy. Journal of Biological Chemistry 273 18185-18190.

Danielson PE, Forss-Petter S, Brow MA, Calavetta L, Douglass J, Milner RJ \& Sutcliffe JG 1988 p1B15: a cDNA clone of the rat mRNA encoding cyclophilin. DNA 7 261-267.

Denef C 1994 Paracrine mechanisms in the pituitary. In The Pituitary Gland, pp 351-378. Ed. J Imura. New York: Raven Press.

Denef C \& Andries M 1983 Evidence for paracrine interaction between gonadotrophs and lactotrophs in pituitary cell aggregates. Endocrinology 112 813-822.

Denef C, Maertens P, Allaerts W, Mignon A, Robberecht W, Swennen L \& Carmeliet P 1989 Cell-to-cell communication in peptide target cells of anterior pituitary. Methods in Enzymology $\mathbf{1}$ 47-71.

Denhardt DT 1966 A membrane-filter technique for the detection of complementary DNA. Biochemical and Biophysical Research Communications 23 641-646.

Denhardt DT \& Noda M 1998 Osteopontin expression and function: role in bone remodeling. Journal of Cellular Biochemistry 30-31 (Suppl) 92-102.

Drouin J, Chamberland M, Charron J, Jeannotte L \& Nemer M 1985 Structure of the rat pro-opiomelanocortin (POMC) gene. FEBS Letters $19354-58$

Escalada J, Cacicedo L, Ortego J, Melian E \& Sanchez-Franco F 1996 Prolactin gene expression and secretion during pregnancy and lactation in the rat: role of dopamine and vasoactive intestinal peptide. Endocrinology 137 631-637.

Ezzat S \& Melmed S 1990 The role of growth factors in the pituitary. Journal of Endocrinological Investigation13 691-698. 
Gubbins EJ, Maurer RA, Lagrimini M, Erwin CR \& Donelson JE 1980 Structure of the rat prolactin gene. Journal of Biological Chemistry 255 8655-8662.

Heuer H, Ehrchen J, Bauer K \& Schä fer MK-H 1998 Regionspecific expression of thyrotrophin-releasing hormonedegrading ectoenzyme in the rat central nervous system and pituitary gland. European Journal of Neuroscience 10 1465-1478.

Hinkle P \& Kinsella PA 1986 Thyroid hormone induction of an autocrine growth factor secreted by pituitary tumor cells. Science 234 1549-1552.

Horvath E \& Kovacs K 1988 Fine structural cytology of the adenohypophysis in rat and man. Journal of Electron Microscopy Technique $\mathbf{8}$ 401-432.

Jin L, Qian X, Kulig E, Scheithauer BW, Calle-Rodrigue R, Abboud C, Davis DH, Kovacs K \& Lloyd RV 1997 Prolactin receptor messenger ribonucleic acid in normal and neoplastic human pituitary tissues. Journal of Clinical Endocrinology and Metabolism 82 963-968.

Lamberts SW \& Macleod RM 1990 Regulation of prolactin secretion at the level of the lactotroph. Physiological Reviews 70 279-318.

Lau LF \& Lam SC 1999 The CCN family of angiogenic regulators: the integrin connection. Experimental Cell Research 10 44-57.

Liang P \& Pardee AB 1992 Differential display of eukaryotic messenger RNA by means of the polymerase chain reaction. Science 257 967-971.

Liaw L, Birk DE, Ballas CB, Whitsit JS, Davidson JM \& Hogan BL 1998 Altered wound healing in mice lacking a functional osteopontin gene (spp1). Journal of Clinical Investigation $\mathbf{1 0 1}$ 1468-1478.

Maurer RA 1987 Molecular cloning and nucleotide sequence analysis of complementary deoxyribonucleic acid for the beta-subunit of rat follicle stimulating hormone. Molecular Endocrinology 1 717-723.

Morel G, Ouhtit A \& Kelly PA 1994 Prolactin receptor immunoreactivity in rat anterior pituitary. Neuroendocrinology 59 78-84.

Ogura K, Nara K, Watanabe Y, Kohno K, Tai T \& Sanai Y 1996 Cloning and expression of cDNA for O-acetylation of GD3 ganglioside. Biochemical and Biophysical Research Communications 225 932-938.

Oldberg A, Franzen A \& Heinegard D 1986 Cloning and sequence analysis of rat bone sialoprotein (osteopontin) cDNA reveals an Arg-Gly-Asp cell-binding sequence. PNAS 83 8819-8823.

Peters A, Heuer H, Schomburg L, de Greef WJ, Visser TJ \& Bauer K 1997 Thyrotropin-releasing hormone gene expression by anterior pituitary cells in long term cultures is influenced by the culture conditions and cell-to-cell interactions. Endocrinology 138 2807-2812.

Qian F, Frankfater A, Miller RV, Chan SJ \& Steiner DF 1990 Molecular cloning of rat precursor cathepsin $\mathrm{H}$ and the expression of five lysosomal cathepsins in normal tissues and in a rat carcinosarcoma. International Journal of Biochemistry 22 1457-1464.

Ray D \& Melmed S 1997 Pituitary cytokine and growth-factor expression and action. Endocrine Reviews 18 206-228.

Renner U, Pagotto U, Arzt E \& Stalla GK 1996 Autocrine and paracrine roles of polypeptide growth factors, cytokines and vasogenic substances in normal and tumorous pituitary function and growth: a review. European Journal of Endocrinology 135 515-532.
Rickard DJ, Sullivan TA, Shenker BJ, Leboy PS \& Kazhdan I 1994 Induction of rapid osteoblast differentiation in rat bone marrow stromal cell cultures by dexamethasone and BMP-2. Developmental Biology 161 218-228.

Rittling SR \& Denhardt DT 1999 Osteopontin function in pathology: lessons from osteopontin-deficient mice. Experimental Nephrology 7 103-113.

Rohn WM \& Weigent DA 1995 Cloning and nucleotide sequencing of rat lymphocyte growth hormone cDNA. Neuroimmunomodulation 2 108-114.

Schäfer MK-H \& Day R 1995 in situ hybridization techniques to study processing enzyme expression at the cellular level. Methods in Neuroscience 23 16-44.

Schomburg L 1994 Klonierung und hormonelle Regulation des TRHabbauenden Ektoenzyms. PhD Thesis. University of Hanover.

Seuntjens E, Vankelecom H, Quaegebeur A, Vande Vijver V \& Denef C 1999 Targeted ablation of gonadotrophs in transgenic mice affects embryonic development of lactotrophs. Molecular and Cellular Endocrinology 150 129-139.

Tortonese DJ, Brooks J, Ingleton PM \& McNeilly AS 1998 Detection of prolactin receptor gene expression in the sheep pituitary gland and visualization of the specific translation of the signal in gonadotrophs. Endocrinology 139 5215-5223.

Tso JY, Sun XH, Kao TH, Reece KS \& Wu R 1985 Isolation and characterization of rat and human glyceraldehyde-3-phosphate dehydrogenase cDNAs: genomic complexity and molecular evolution of the gene. Nucleic Acids Research 13 2485-2502.

Umekawa T, Kohri K, Kurita T, Hirota S, Nomura S \& Kitamura Y 1995 Expression of osteopontin messenger RNA in the rat kidney on experimental model of renal stone. Biochemistry and Molecular Biology International 35 223-230.

Vanderschueren B, Denef C \& Cassimin JJ 1982 Ultra-structural and functional characteristics of rat pituitary cell aggregates. Endocrinology $110513-523$

Wada J, Kumar A, Liu Z, Ruoslahti E, Reichardt L, Marvaldi J \& Kanwar YS 1996 Cloning of mouse integrin alphaV cDNA and role of the alphaV-related matrix receptors in metanephric development. Journal of Cell Biology 132 1161-1176.

Xu J, Smock SL, Safadi FF, Rosenzweig AB, Odgren PR, Marks SC, Owen TA \& Popoff SN 2000 Cloning the full-length cDNA for rat connective tissue growth factor: implications for skeletal development. Journal of Cellular Biochemistry 77 103-115.

Yeh TC, Wilson AC \& Irwin DM 1993 Evolution of rodent lysozymes: isolation and sequence of the rat lysozyme genes. Molecular Phylogenetics and Evolution 2 65-75.

Yoshitake H, Rittling SR, Denhardt DT \& Noda M 1999 Osteopontin-deficient mice are resistant to ovariectomy-induced bone resorption. PNAS 96 8156-8160.

Received in final form 19 October 2000

Accepted 8 December 2000 